\title{
URGENSI KONSELING MULTIKULTURAL DI SEKOLAH
}

\author{
Elizar *)
}

\begin{abstract}
Every culture certainly has a different customs that will form the habit of a student in being. When the counselor and counselee met in the counseling process the counselor should first understand its cultural background.The counselling needed as solutions to the problems that arise. Morever faced conselors consist of student of different cultural background. Theefore, cross cultural counselor mus be aware ofthe studental values wich prssesses, second, crosss cultural counselor must be aware of the characteristics of counseling in general, third croos-cultural counselor must be aware of the influence of ethnicity and they must have attention to surroundings, fourth, croos-cultural counselor could not encourage one client to understanding the culture or te values owned counselors, and fifth cross-cultural counselor in implementing counseling must use ecletic approach. The counselor with a keen sensitivity better understand and appreciate the cultural bias between the counselor and counselee which is predicted to be able to direct the counselee to develop optimally.
\end{abstract}

Key Word: Konseling, konsle, and multikultural.

\section{PENDAHULUAN}

Konseling merupakan suatu proses untuk membantu individu mengatasi hambatan-hambatan perkembangan dirinya dan untuk mencapai perkembangan yang optimal kemampuan pribadi yang dimilikinya. Proses tersebut dapat terjadi jika ada hubungan individu untuk mengungkapkan kebutuhan-kebutuhan, motivasi, dan potensi-potensi yang unik dari individu sebagai suatu masalah yang memerlukan bantuan untuk solusi dari orang yang profesional. Mengingat individu yang dibantu berasal dari latar belakang budaya yang berbeda, diperlukan pemahaman yang dalam pelayanan konseling.
Konseling multikultural yang dikenal juga dengan konseling lintas budaya (crossculture counseling) merupakan salah satu bentuk konseling untuk dapat memahami klien dengan latar belakang karakteristik yang berbeda-beda. Di sekolah sangat tepat dilakukan seorang konselor/guru sebagai petugas konseling yang menghadapi siswa dari latar budaya yang berbeda.

Proses konseling sangat rawan untuk terjadinya bias-bias budaya pada pihak konselor yang mengakibatkan konseling tidak berjalan efektif. Agar berjalan efektif, konseling konselor dituntut untuk memiliki kepekaan budaya dan melepaskan diri dari bias-bias budaya, mengerti dan dapat mengapresiasi diversitas budaya dan 
memiliki keterampilan-keterampilan yang responsive secara kultural.

Di sekolah hal ini belum sepenuhnya mendapat perhatian sehingga penerapan konseling pada siswa belum berjalan sebagaimana mestinya. Bolton-Brownlee dalam Nugraha (2012:7) menyatakan proses konseling yang dilakukan oleh konselor sejauh ini hanya menitikberatkan pada aspek-aspek psikologis (kecerdasan, minat, bakat, kepribadian, dll) dan masih kurang memperhatikan terhadap latar belakang budaya konselor maupun konseli yang ikut membentuk perilakunya dan menentukan efektivitas proses konseling. Pembahasan berikut akan mendeskripsikan tentang konsep konseling multikultural dan urgensinya sebagai bentuk sensitivitas dalam memberikan pelayanan pada siswa yang berasal dari latar belakang budaya yang berbeda.

\section{PENGERTIAN KONSELING MULTIKULTURAL}

Konseling multikultural dikenal juga dengan konseling lintas budaya mempunyai arti suatu hubungan konseling yang terdiri dari dua peserta atau lebih, berbeda dalam latar belakang budaya, nilai-nilai dan gaya hidup (Sue dkk, dalam Nugraha, 2012:7). Definisi yang dikemukakan di atas telah memberikan definisi konseling multikultural secara luas dan menyeluruh. Konseling multikultural melibatkan koselor (pemberi penyuluh) dan konseli (individu yang menerima penyuluhan atau klien) yang berasal dari latar belakang yang berbeda. Oleh karena itu, konselor perlu menyadari dan peka akan nilai-nilai yang berlaku secara umum.

Konseling multikultural tentunya menuntut kedua belah pihak untuk memahami budaya dari keduanya. Untuk menjalankan konseling multikultural yang efektif seorang konselor mempunyai ciri atau karakteristik. Karakteristik yang dimiliki konselor multikultural: mempunyai kesadaran budaya, paham karakteristik konseling seacara umum, menunjukkan empati budaya dan sebagainya.

Adanya keragaman budaya merupakan realitas hidup, yang tidak dapat dimungkiri mempengaruhi perilaku individu dan seluruh aktivitas manusia, yang termasuk di dalamnya adalah aktivitas konseling. Karena itu, dalam melakukan konseling, sangat penting untuk mempertimbangkan budaya yang ada. Namun, dalam kenyataannya, kesadaran budaya dalam praktek konseling masih sangat kurang.

Dalam cakupan budaya Pedersen, Crether \& Carlson (Nugraha, 2012:44) memaparkan sebagai berikut "cultural empahty is therefore the learned ability of counselors to accurately understand and respond appropriately to each culturally different client." Dapat dipahami empati budaya adalah kemampuan konselor untuk 
memahami secara akurat dan respon yang tepat terhadap perbedaan budaya konseli. Hal tersebut mengisyaratkan bahwa empati merupakan suatu kemampuan bagi seorang konselor dalam memahami dan merasakan latar belakang kehidupan yang dibawa oleh konseli dan berpengaruh terhadap keadaan konseli saat proses konseling berlangsung.

Dalam penyelenggaraan pendidikan di sekolah, kesadaran budaya harus menjadi tujuan pendidikan, termasuk konseling yang harus sesuai dengan kondisi siswa sebagai klien yang memiliki latar budaya yang berbeda-beda. Hubungan klien dan konselor selalu dipengaruhi oleh budaya dan latar belakang klien dan latar belakang konselor. Aspek lain yang juga penting dalam konseling yaitu teori, tempat layanan dan proses konseling. Tempat layanan konseling berlangsung juga mempunyai nilai budaya sendiri yang juga penting dipertimbangkan dalam melakukan konseling.

Konselor dan guru di sekolah sebagai petugas konseling dalam perumusan tujuan konseling diwarnai pengaruh budaya klien, pribadi konselor, lingkungan dan teori yang digunakan. Dalam perkembangannya, hampir selalu menggunakan pendekatan yang sarat nilai-nilai barat, karena itu pendekatan yang digunakan tidak selalu efektif dipraktekkan, terutama dalam setting yang berbeda dengan budaya barat. Kenyataan seperti ini yang mendorong beberapa tokoh konseling untuk mengembangkan konseling multikultural.

Nuzliah (2016:212) mengemukakan tujuan konseling multikultural adalah: 1) Membantu klien agar mampu mengembangkan potensi-potensi yang di miliki meberdayakan diri secara optimal, 2) Membantu klien multikultural agar mampu memecahkan masalah yang dihadapi, mengadakan penyesuaian diri, serta merasakan kebahagiaan hidup sesuai dengan budayanya, 3) Membantu klien agar dapat hidup bersama dalam masyarakat multicultural dan 4) Memperkenalkan, mempelajari kepada klien akan nilai-nilai budaya lain untuk di jadikan revisi dalam membuat perancanaan, pilihan, keputusan hidup kedepan yang lebih baik

Fenomena yang terjadi salah satu faktor gagalnya proses konseling adalah persepsi yang dimilki oleh konselor tidak sama dengan persepsi yang dimiliki oleh konseli disebabkan berbedanya latar belakang budaya yang dimiliki konselor dan klien. Hal inipun terjadi di sekolah yang memiliki guru dan siswa dari latar belakang budaya yang berbeda. Untuk itu seorang konselor maupun guru sebagai petugas konselor harus mengembangkan kemampuan dalam konseling multikultural. Dengan demikian dapat memberikan layanan konseling yang efektif pada siswa. 


\section{KARAKTERISTIK KONSELOR MULTIKULTURAL}

Hays \& Erford (2010:30) yang menyatakan bahwa konselor yang peka adalah konselor yang mengerti dan paham terhadap perbedaan dan keberagaman budaya pribadi konselor dan konseli yang dihadapi dalam layanan konseling. Dalam pelaksanaan konseling multikultural, konselor harus mempunyai karakteristik yang dipersyaratkan. Dari berbagai sumber dapat digambarkan bahwa konselor multikultural harus memiliki karakteristik: (1) kesadaran terhadap nilai-nilai pribadi yang dimilikinya dan asumsi asumsi terbaru tentang perilaku manusia; (2) kesadaran memiliki nilai nilai sendiri yang harus dijunjung tinggi; (3) menerima nilai-nilai yang berbeda dari klien dan mempelajarinya; (4) kesadaran terhadap karakteristik konseling secara umum; (5) kesadaran terhadap kaidah-kaidah dalam melaksanakan konseling; (6) mengetahui pengaruh kesukuan dan perhatian terhadap lingkungannya; (7) tanggap terhadap perbedaan yang berpotensi menghambat proses konseling; (8) tidak boleh mendorong klien untuk dapat memahami budaya dan nilai-nilai yang dimiliki konselor.

Dari gambaran karakteristik tersebut dapat disimpulkan bahwa konselor multikultural sadar terhadap nilai-nilai pribadi yang dimiliki dan asumsi-asumsi terbaru tentang prilaku manusia. Konselor sadar bahwa dia memiliki nilai-nilai sendiri yang dijunjung tinggi dan akan terus dipertahankan.

Di sisi lain konselor juga menyadari bahwa klien memiliki nilai-nilai dan norma yang berbeda dengan dirinya dan sebagai suatu konsekwensi dari tugasnya pula sebagai konselor maka konselor multikultural sadar terhadap karateristik konseling secara umum. Dalam hal ini konselor memiliki pemahaman yang cukup mengenai konseling secara umum sehingga akan membantunya dalam melaksanakan konseling.

Dalam dunia pendidikan, konselor maupun guru yang melakukan konseling mempertimbangakan aspek budaya siswa yang berbeda harus mengetahui pengaruh kesukuan dan mereka mempunyai perhatian terhadap lingkungannya dan konselor dalam tugasnya harus tanggap terhadap perbedaan yang berpotensi untuk menghambat proses konseling.terutama yang berkaitan dengan nilai, norma dan keyakinan yang dimiliki oleh suku agama tertentu.

Dengan pemahaman pada klien konselor multikultural tidak boleh mendorong klien untuk dapat memahami budaya dan nilai-nilai yang dimiliki konselor. Ada aturan main yang harus ditaati oleh setiap konselor karena konselor mempunyai kode etik konseling yang secara tegas menyatakan bahwa konselor tidak boleh memaksakan kehendaknya kepada klien. 
Terakhir sebagai suatu konsekwensi karena perbedaan buadaya itulah maka konkonselor lintas budaya dalam melaksanakan konseling harus memper-gunakan pendekatan ekletik. Pendekatan ekletik ini adalah suatu pendekatan dalam konseling yang mencoba untuk menggabungkan beberapa pendekatan dalam konseling untuk membantu memecahkan masalah klien.

Dalam praktiknya di sekolah seorang konselor maupun guru sebagai petugas konseling tidak memberlakukan siswa secara sama dalam proses konseling, tetapi perlakukan sesuai dengan karakteristik siswa. Pandangan pakar konseling, pendidikan yang tidak melihat budaya klien adalah pendidikan yang menindas. Kesadaran budaya harus menjadi tujuan pendidikan agar konseling pada klien lebih sesuai dan penyelesaian masalah lebih efektif.

\section{URGENSI PENERAPAN KONSELING MULTIKULTURAL DI SEKOLAH}

Kompleksitas dan keragaman budaya ini pada kondisi normal dapat menumbuhkan keharmonisan hidup. Namun, dalam kondisi bermasalah dapat menimbulkan hambatan dalam berkomunikasi dan penyesuaian antar budaya. Budaya dalam hal ini memiliki arti sebagai tingkah laku, pola-pola keyakinan dan semua produk dari kelompok manusia tertentu yang diturunkan dari generasi ke generasi. Produk itu adalah hasil dari interaksi antara kelompok manusia dengan lingkungan mereka setelah sekian lama. Konseling sendiri memiliki arti suatu proses untuk membantu individu mengatasi hambatan-hambatan perkembangn dirinya, dan untuk mencapai perkembangan yang optimal kemampuan pribadi yang dimilikinya, proses tersebuat dapat terjadi setiap waktu. Kajian Multikultural adalah memahami keragaman budaya yang ada di dunia sekaligus dampak budaya tersebut terhadap kelangsungan masyarakat sosial dalam lingkup budaya tertentu.

Pedersen, Lonner dan Draguns (dalam Hardiyanto, 2017) mengemukakan suatu kontinum kesadaran konseling multikultural yang harus dilewati konselor sebelum ia melaksanakan konseling multikultural. Kontinum ini dimulai dari kesadaran konselor akan dirinya, termasuk kesadaran akan prasangka-prasangka yang dimilikinya. Kesadaran diri diikuti oleh terbentuknya kesadaran akan kebudayaannya sendiri, kepekaan akan adanya berbagai ras, seksisme, dan kemiskinan di dalam masyarakat.

Kesadaran akan adanya perbedaan individual, kesadaran akan adanya kelompok-kelompok budaya lain dan keanekaragamannya, dan akhirnya pengembangan teknik-teknik konseling yang memungkinkan konselor menjembatani jarak antara dirinya, pribadinya, dan konseli yang 
berbeda budayanya menjadikan konseling multikultural multi kulturan sebagai sesuatu yang urgen dilaksanakan. Urgensi dalam penerapannpannya tersebut dapat dijelaskan sebagai berikut.

\section{Kesadaran diri}

Kesadaran diri, hal pertama yang harus dilalui konselor memahami diri sendiri sangat diperlukan sebelum memahami orang lain. Dinamika interpersonal dan intrapersonal harus dianggap sebagai komponen yang penting dalam proyeksi keyakinankeyakinan, sikap, pendapat dan nilai-nilai. Pengujian tentang pemikiran-pemikiran dan perasaan-perasaan seseorang memungkinkan konselor untuk memahami lebih baik tentang muatan budaya yang dibawa oleh klien.

\section{Kesadaran akan budaya sendiri}

Kesadaran akan budaya sendiri, memberi wawasan kepada konselor berbeda dengan klien. Dari pemberian nama seorang klien saja tampak pengaruh budaya beragam. Demikian juga tentang bahasa, khusus untuk bagi kelompok budaya klien dalam bentuk formal maupun informal. Bahasa menentukan jaringan kerja budaya dimana partisipasi individu dan kontribusi nilai-nilai spesifik terhadap budaya diri klien.

\section{Kesadaran akan ras, seksisme, dan kemiskinan}

Aspek kebudayaan seperti; ras, seksisme, dan kemiskinan harus dipahami dari perspektif tentang bagaimana seseorang memandang efek baik terhadap diri sendiri maupun orang lain. Ketika rasisme dan seksisme ditolak sebagai bagian dari sistem keyakinan pribadi, ia harus mengakui bahwa bagaimanapun juga ada sebagian dari budaya yang lebih besar. Bahkan, ketika penderitaan dari kemiskinan tidak dirasakan secara pribadi, konselor harus berusaha dengan keyakinannya memperhatikan orang-orang yang kurang beruntung secara finansial.

\section{Kesadaran akan perbedaan individual}

Konselor kadang terperankap dalam over generalisasi. Dalam kondisi ini hal-hal khusus dari kebudayaan perlu dipelajari. Dalam konseling, konselor harus menangani semua konseli sebagai individu-individu dan anggota dari kelompok budaya khusus mereka. Konselor harus menyadari perbedaan-perbedaan individual dan semakin yakin terhadap keunikan individu sebelum beralih ke level kesadaran tentang budayabudaya lain.

\section{Kesadaran akan budaya-budaya lain}

Dari keempat pembahasan mengenai kesadaran konseling multikultural di atas telah memberikan gambaran yang perlu bagi konselor dalam mempelajari beragam dinamika kelompok kebudayaan lain. Bahasa mempunyai arti yang besar dan khas pada masing-masing kelompok kebudayaan, saat ini sebagian besar penekanan multikultural mengarah pada orang-orang dengan latar 
negara maju. Perlu bagi seorang konselor untuk mapan terhadap kata-kata yang khas pada suatu kebudayaan khusus seperti bahasa tubuh dan perilaku non-verbal lainnya.

\section{Kesadaran akan keanekaragaman}

Konselor harus menyadari keberagaman kebudayaan yang dapat saling mempengaruhi menjadi peleburan sebagai akulturasibudaya. Pengarakterisasian ini menggambarkan bahwa orang-orang datang ke suatu daerah yang berbeda dan bercampur menjadi satu kedalam satu kebudayaan baru. Dengan demikian kebiasaan tempat yang lama telah berubah, dikesampingkan, atau dipertahankan ke dalam konteks kebudayaan baru.

\section{Keterampilan akan teknik-teknik konseling}

Terakhir dalam kontinum konseling multikultural ialah meng- implementasikan apa yang telah dipelajari tentang bekerjanya kelompok budaya yang berbeda dan memasukkan teknik-teknik khusus dalam daftar keterampilan konseling. Agar konselor dapat bekerja secara efektif dengan konseli, konseli harus mengetahui teori belajar dan bagaimana teori berhubungan dengan perkembangan faktor-faktor psikologis budaya. Selain teori, konselor juga mampu menghubungkan dengan strategi-strategi atau praktik konselor. Hal paling penting, sebelum melakukan konseling yang berbeda budaya maka konselor harus menghargai budayanya sendiri.

Dalam konseling, tidak hanya terdapat hubungan dua arah, yakni konselor dan konseli melainkan hubungan tiga arah, yakni konselor, konseli dan budaya. Ketika konselor bekerja dengan orang yang gaya hidupnya berbeda dari budaya konselor untuk setiap waktu, konselor dapat berpartisipasi dan membantu terhadap proses akulturasi melalui dirinya dan melalui konselinya.

Dari uraian di atas dapat disimpulkan bahwa konseling multikultural ini sangat penting dipelajari oleh seorang calon konselor maupun konselor agar konselor dapat menyadari keberadaan budaya klien dan tidak sensitif terhadap kebudayaan klien. Kebudayaan klien dapat menghargai perbedaan dan hal itu dapat membuat konselor akan merasa nyaman bekerja dengan memahami karakter dan latar belakang budaya yang berbeda-beda, dengan karakteristiknya. Dengan demikian, klien nantinya dapat mengikuti proses konseling dengan baik, klien dapat membuka diri dapat merasa dihargai dalam proses konseling. Di sini klien tidak merasa beda karena perbedaan budaya yang dimilikinya. Sebab itulah yang mengakibatkan konseling multikultural menjadi penting.

Perbedaan ras, etnik, kebudayaan, dan kepercayaan dalam konseling multi- kultural dijadikan variabel dan objek perhatian yang 
mungkin mempengaruhi struktur kepribadian, pilihan karir, manifestasi gangguan psikologis, perilaku mencari bantuan, dan kecocokan dan ketidakcocokan dari klien dan pendekatan konseling yang akan digunakan konselor.

Konseling multikultural atau konseling multikultural sangat tepat untuk lingkungan yang berbudaya plural seperti di Indonesia. Bimbingan dan konseling dilaksanakan dengan landasan semangat bhineka tunggal ika, yaitu kesamaan di atas keragaman. Meski demikian, pendekatan konseling multikultural tidak mengabaikan pendekatan tradisional yang selama ini digunakan, melainkan dengan mengintegrasikannya dengan perspektif budaya Indonesia yang beragam. Konselor perlu bersikap proaktif terhadap perbedaan budaya, mengenali dan menghargai budaya setiap konseli. Konselor dituntut memiliki kesehatan mental yang baik, fleksibel, menghindari keyakinan etnosentris atas keunggulan budaya, agama, dan gaya hidupnya. Wolfgang, dkk (2011:7) menjelaskan sebagai konselor, mampu mengalihkan perhatian mereka untuk melakukan konseling serta memasukkan isuisu lintas budaya yaitu dengan metode klinis.

Di sekolah tuntutan ini tentu akan menjadi lebih menuntut guru bimbingan dan konseling, di mana tujuan dari bimbingan dan konseling itu sendiri adalah agar peserta didik mampu, 1) merencanakan kegiatan penyelesaian studi, perkembangan karir serta kehidupannya di masa yang akan datang, 2) mengembangkan seluruh potensi dan kekuatan yang dimiliki seoptimal mungkin, 3) menyesuaikan diri dengan lingkungan pendidikian, lingkungan masyarakat serta lingkungan kerja, serta 4) mengatasi hambatan dan kesulitan yang dihadapi dalam studi, penyesuaian dengan lingkungan pendidikan, masyarakat, maupun lingkungan kerja (Nugraha, 2012).

Gumilang (2015:49) konselor sekolah dalam menghadapi beragam perbedaan konseli, perlu mengubah persepsi mereka, belajar tentang konseling dan konsultasi, mencukupkan diri dengan pengetahuan tentang budaya lain, bentuk rasisme dan berperan sebagai agen perubahan sosial. Dalam memberikan layanan bimbingan dan konseling, konselor perlu memperhatikan kesadaran budaya karena mampu membawa konseli memahami karakteristik psikologis seperti kecerdasan (intelegensi, emosional, dan spiritual), bakat, sikap, motivasi, dan lain-lain.

Dalam pelayanan bimbingan dan konseling di sekolah, guru bimbingan dan konseling/konselor sekolah diharuskan memiliki kesadaran multikultural, memahami keberagaman konseli, menghargai perbedaan dan keragaman nilai-nilai, keyakinan-keyakinan, menyadari adanya bias-bias dan kesadaran akan keterbatasan diri dalam hal budaya. Memahami 
pandangan hidup dan latar belakang budaya diri dan konseli serta mengembangkan strategi konseling yang sesuai budaya, mengingat keragaman tersebut saling berinteraksi dalam komunitas sekolah sebagai akibat dari tren atau kecenderungan demografi.

Layanan konseling di sekolah harus dilihat dalam perspektif budaya, yakni proses konseling merupakan proses interaksi dan komunikasi yang intensif antara konselor dengan konseli yang didalamnya terjadi perjumpaan budaya antara konselor dengan konseli. Oleh karena itu, konselor perlu memiliki kepekaan budaya agar dapat memahami dan membantu konseli sesuai dengan konteks budayanya, menyadari benar bahwa secara kultural, individu memiliki karakteristik yang unik dan dalam proses konseling akan membawa karakteristik tersebut. Pemahaman konseling multikultural atau konseling berwawasan multikultural ini efektif untuk mengeleminir kemungkinan munculnya perilaku konselor yang menggunakan budayanya sendiri (counselor encaptulation).

\section{PENUTUP}

Konseling dibutuhkan sebagai suatu solusi dari permasalahan yang berbeda-beda dan dari latar belakang siswa yang berbedabeda. Penerapan konseling multikultural di sekolah sangat penting, hal ini akan memberikan rasa aman bagi klien. Klien akan lebih percaya diri apabila berkonsultasi dengan konselor/guru sebagai petugas konseling yang paham dengan dirinya dan latar belakangnya. Di sekolah konselor/guru sebagai pelaksana konseling lintas budaya harus memiliki karakteristik. Pertama konselor lintas budaya harus sadar terhadap nilai-nilai pribadiyang dimilikinya, kedua harus sadar terhadap karakteristik konseling secara umum, ketiga harus mengetahui pengaruh kesukuan dan mereka harus mempeunyai perhatian terhadap lingkungan, keempat tidak boleh mendorong seseorang klien memahami budayanya. Diharapkan dengan pahamnya konselor dan diterapkannya konseling multikultural maka siswa sebagai klien menjadi lebih nyaman dalam pelayanan dan lebih efektif dalam memberikan solusi dari masalah klien.

\section{DAFTAR RUJUKAN}

Gumilang, Galang Surya. 2015. Urgensi Kesadaran Budaya Konselor dalam Melaksanakan Layanan Bimbingan dan Konseling. Dalam Jurnal Guinea-Ilmu Pendidikan, Psikologi dan Bimbingan Konseling, Vol 2.2(2) $47-48$.

Hadiwinarto, 2018. Konseling Lintas Budaya Berbasis Sumber Daya Lokal dan Kebencanaan. (Online Journal) (diunduh 10 Agustus 2018). Tersedia dari: http://ojs.unpatti.ac.id/index.php/bkt 
Hays, Danica G. \& Erford, Bradley T. 2010. Developing Multicultural Counseling Competence: A Systems Approach.New Jersey: Pearson.

Nugraha, Agung. 2012. Program Experiential Based Group Counseling Untuk Meningkatkan Kepekaan Multibudaya Calon Konselor (Penelitian Pra Eksperimen di Jurusan PPB FIP UPI Tahun Akademik 2011/2012). Tesis. Bandung: SPs UPI (tidak diterbitkan).

Nuzliah. 2016. Konseling Multikultural. Dalam Jurnal Educasi UINAr.Rainy, Vol 2 (2): 212-213.

Pedersen, Paul B., Crether \& Carlson. 2008 Inclusive Cultural Empathy; Making Relationships Central in Counseling and Psychotherapy. Washington D.C: APA.
Sue, D. W. \& Sue, D. 2003. Counseling the Culturally Diverse; Theory and Practice. USA: John Wiley \& Sons, Inc.

Syafri, Fatrida Anugrah, 2017. Pemantapan Psychological Self Concept Peserta Didik Minoritas Melalui Konseling Lintas Budaya Dan Agama. (Online Journal) (diunduh 10 Agustus 2018). Journal of Innovative Counseling: Theory, Practice \& Research (2017), 1(1):78-79.

Wolfgang, J., Frazier, K., Olatunji, C.W., Barrett J. 2011. Developing Cross Cultural Competence: Applying Development and Prevention Ideals to Counseling Young Children. Association for Counselor Educators and Supervisors (ACES). 